\title{
Qualification (Mis)Match for Upper Secondary and Higher Education
}

\author{
Mariya Neycheva
}

check for

updates

Citation: Neycheva, Mariya. 2021. Qualification (Mis)Match for Upper Secondary and Higher Education. Social Sciences 10: 327. https:// doi.org/10.3390/socsci10090327

Academic Editor:

Queralt Capsada-Munsech

Received: 22 May 2021

Accepted: 27 August 2021

Published: 30 August 2021

Publisher's Note: MDPI stays neutral with regard to jurisdictional claims in published maps and institutional affiliations.

Copyright: (C) 2021 by the author. Licensee MDPI, Basel, Switzerland. This article is an open access article distributed under the terms and conditions of the Creative Commons Attribution (CC BY) license (https:// creativecommons.org/licenses/by/ $4.0 /)$.
Faculty of Business Studies, Burgas Free University, 8000 Burgas, Bulgaria; mneicheva@abv.bg

\begin{abstract}
The expansion of education all over the world is expected to improve economic and social development. However, the oversupply of educated labor force might bring unfavorable consequences for the labor market and long-run growth prospects. In this regard the purpose of this paper is two-fold. First, it aims at summarizing the main channels and mechanisms through which education-job mismatch could impact the changes of per capita income. Second, the study presents empirical evidence on that impact by differentiating between qualification mismatch among workers having completed tertiary education and those with upper secondary education. The sample comprises the EU member countries between 2000 and 2019. The results suggest that whereas the higher percentage of the properly matched labor force increases the steady-state level of per capita output for both educational levels being considered, the effect of qualification mismatch is either negative or insignificant. There is some evidence that overeducation among higher education graduates exhibits a stronger negative effect on economic activity in comparison with overeducation among workers with upper secondary education.
\end{abstract}

Keywords: qualification mismatch; overeducation; tertiary education; upper secondary education; growth

\section{Introduction}

The rising educational attainment of the population is accompanied by a rising education-job mismatch in the developed world. Across the European Union members, the rate of overeducation among workers with college or university education has increased by more than $45 \%$ over the last two decades. The respective number of employees having completed upper secondary education is 41 . In terms of the interrelationships between the labor market and aggregate activity, the tendency that part of the most educated human capital has been moving down the occupational ladder is expected to influence output and per capita income in the long run. Though the fundamental theoretical models relating human capital and economic growth does not explicitly differentiate between the properly matched and mismatched graduates (e.g., Mankiw et al. 1992; Lucas 1988; Romer 1986; Islam 1995; Nonneman and Vanhoudt 1996), it is reasonable to expect that they would differ in their impact. Thus, the issue deserves more attention taking into consideration that few papers address it explicitly. In response to that, the present study, on the one hand, discusses the theoretical channels and mechanisms through which vertical qualification (mis)match might influence aggregate activity and, on the other hand, presents empirical evidence on that influence.

The (mis)match between education attained by an employee and the educational requirements of the job one performs might influence economic activity by different channels and mechanisms. According to the theory of human capital, rising educational attainment is expected to increase productivity by developing and upgrading an individual's skills and knowledge. In the case of perfectly competitive markets, the real wage should equal the worker's marginal product. All other things being equal, over/under-qualified employees earn higher/lower wages than their well-matched peers, thus signaling differences in their 
productivity (Quintini 2011). Since productivity is positively linked to income per capita growth, a rise in overqualification among employees is expected to enhance the long-run growth prospects.

It must be noted that the abovementioned explanation suffers from two major drawbacks. It implies that the human capital stock possessed by an individual is the primary factor determining his or her productivity. Additionally, it assumes that the wage equals the marginal worker productivity. Thus, a higher/lower wage is considered an indicator of higher/lower productivity. However, in the case of market failures such as imperfectly competitive markets, collective bargaining, employers' discriminating practices, or rent-seeking behavior, the higher wage of an overeducated worker does not necessarily mean higher productivity. Moreover, in terms of Spence's theory (Spence 1973), the higher education degree is a signal for higher qualification motivating employers to pay more to university graduates without considering their productivity (see, also Garcia-Mainar and Montuenga 2019). All that might lead to wrong conclusions for the impact of qualification mismatch on productivity and, hence, growth.

Among the empirical studies which find a positive relation between over-education and productivity, are those of Van der Meer (2006) and McGuinness and Sloane (2011). Opposite to them, Rumberger (1987) points out that the years over the required schooling do not increase productivity significantly since workers cannot fully utilize the additional skills and capabilities being acquired at school. On the other hand, using data from Belgian firms, the study of Mahy et al. (2015) implies that the direct impact of overeducation on productivity is conditional upon a number of factors such as a higher share of high-skilled jobs in the country, knowledge-intensive industries, as well as some degree of uncertainty of the economic environment.

An alternative explanation of the link between qualification mismatch and productivity arises from the theories in the field of organizational behavior, which relates mismatch to job satisfaction. Workers with higher than the required level of education would not be fully satisfied by their current occupation which might be harmful to their productivity. Additionally, decreasing satisfaction at work would lead to a higher job turnover especially for educated individuals, thus affecting a firm's performance negatively. Contrary to the previous explanation, this implies a negative relation between qualification mismatch, productivity, and the real growth rate. Following this line of thinking, support for such an adverse effect of mismatch on job satisfaction could be found in Tsang et al. (1991); Sloane et al. (1999); Verhaest and Omey (2009). Yet, another strand of literature indicates that more than required educated workers possess characteristics such as consciousness (Barrick and Mount 1991) or better work attitude (Weiss 1995) which are positively correlated to their productivity.

Besides the abovementioned within-firm effects, economic growth might be influenced by the reallocation effects of qualification mismatch on aggregate productivity. McGowan and Andrews (2015) claim that in an economy where companies with different productivity levels co-exist, the less effective ones might hire the over-skilled labor, thus not allowing for that labor to be efficiently utilized by more productive companies. This results in resource misallocation and lower productivity at a national level which consequently harms long-run growth potential.

A few papers have examined the direct effect of qualification mismatch on wages and returns of schooling (see, e.g., Bauer 2002; Dorn and Sousa-Poza 2005). Verdugo and Verdugo (1989) found a negative effect on wages of persons who possess education higher than the mean education of those in the same occupational group. Hartog (2000, p. 135) pointed out that, overall, the returns of overeducation though positive are lower than the returns for just matched education. According to the ORU (over-, required-, and under-qualification) specification, one additional year of overeducation leads to a lower wage premium compared to one additional year of schooling required for one's occupation. The former varies from half to two-thirds of the latter which means that individuals with excess qualification face wage penalties compared to those who possess the right level 
of education for the job they hold. The returns of under-schooling appear to be negative. All these estimates imply that a higher extent of mismatch in an economy, especially the overqualification, would lead to a downward bias of the overall returns of education which consequently might suppress the growth rate.

Technology adoption or investments is the next channel of influence of mismatch on growth, which is worth mentioning. Studies show that skill shortages reduce investments and R\&D spending (Forth and Mason 2006). In light of this, it is reasonable to assume that under-qualification or poor quality of education, even in the case of many overeducated, would negatively affect growth as long as skills are related to qualification. On the other hand, the rising educational attainment and possibly overeducation in a certain economy might attract investors' attention, thus stimulating capital formation and growth.

The next channel concerns vacancies and the rate of unemployment. The differences between the qualification being supplied by the graduates and the qualification, skill, and competencies being demanded by employers could prevent the latter from hiring the mismatched workers. This is expected to increase structural long-term unemployment (Lucifora and Origo 2002; Birk 2001) which adversely affects aggregate supply.

To the authors' knowledge, the only two studies which have investigated the link between education mismatch and growth are those of Jaoul-Grammare and Guironnet (2009) and Ramos et al. (2009). The studies produced contradicting outcomes and did not discuss explicitly the theoretical aspects of that relationship. The first paper estimated the causality between overeducation, wages, and growth in France. It found that the higher share of overeducated workers with a university degree exerts an unfavorable pressure on GDP at least in the short run by decelerating its rate of growth.

The paper of Ramos et al. (2009) utilizes two measures of vertical mismatch. A person is considered overeducated if his or her years of schooling are above the mode for a particular occupation in a given region and country. The second measure is based on the match between educational levels according to ISCED levels and occupations according to ISCO. The sample comprises 26 NUTS-I regions, 72 NUTS-II regions, and 164 NUTS-III regions across six European countries-Austria, France, Greece, Ireland, Portugal, and Spain. Contrary to the previous study, this study indicates an existence of a positive statistically significant correlation between overeducation and the rate of real GDP increments at a regional level. The result for the undereducated is negative. The outcome is explained by the opportunity for the educated workforce to take advantage of qualified jobs.

The abovementioned review confirms that the effects of (mis)match on economic activity are still underexplored. This paper aims to partly fill this gap by examining the link between over-, under-, and just-educated workers and the equilibrium per capita income level in the European economies. A major contribution is that the study differentiates between the effect on per capita aggregate output of vertical (mis)match among tertiary education graduates and (mis)match among an active population with upper secondary education. The general hypothesis being tested here is that both over- and under-education negatively affect long-run per capita income. The sample comprises the EU-28 member states between 2000 and 2019, excluding Greece ${ }^{1}$. The degree of mismatch is measured by applying the static approach assuming fixed mapping between one's educational degree completed according to the ISCED (International Standard Classification of Education) framework and occupations based on International Standard Classification of Occupations (ISCO) (Eurostat 2009, p. 132).

The structure of the paper is as follows. Section 2 outlines the methodology of the study while Section 3 displays empirical results of the baseline models. Section 4 presents the robustness checks, discusses the results, and proposes some explanations. Section 5 provides some concluding remarks. 


\section{Methodology of the Study}

The study modifies the widely used neoclassical model of economic growth with human capital (Mankiw et al. 1992; Islam 1995) by differentiating between vertically matched and vertically mismatched active population as the latter includes both over- and undereducated individuals. The next paragraphs describe the theoretical foundations of the empirical models. The Cobb-Douglas aggregate production takes the form:

$$
Y_{t}=A_{t} K_{t}^{\alpha} \mathrm{Hm}_{t}{ }^{\beta} \mathrm{Hmis}_{t}{ }^{\gamma} L_{t}{ }^{(1-\alpha-\beta-\gamma)}
$$

where $Y$ is output, and $K$ denotes the stock of physical capital. The human capital $(\mathrm{H})$ is divided into two components: $\mathrm{Hm}$ denotes just-matched labor force, whereas Hmis represents the stock of over- and undereducated. $\mathrm{K}, \mathrm{Hm}$, and Hmis depreciate at the same exogenous rate $\delta$. The supply of labor $(L)$ is growing at rate $n$, while the level of technology $(A)$ changes at rate $g$. The constants $\alpha, \beta$, and $\gamma$ measure the elasticity of production inputs. The dynamic path of the capital inputs expressed in effective units of labor can be described as:

$$
\begin{aligned}
& \dot{k_{t}}=s_{k} * y_{t}-(n+g+\delta) * k_{t} \\
& \dot{h m_{t}}=s_{h m} * y_{t}-(n+g+\delta) * h m_{t} \\
& \text { hmis }_{t}=s_{\text {hmis }} * y_{t}-(n+g+\delta) * h_{m i s_{t}}
\end{aligned}
$$

The small letters- $k=K / A L, h m=H m / A L, h m i s=H m i s / A L$ and $y=Y / A L$ are for the quantities per an effective labor unit whereas $s_{k}, s_{h m}$, and $s_{h m i s}$ are the rates of accumulation of physical capital and the two components of human capital, respectively. The assumption of diminishing returns to capital implies that $\alpha+\beta+\gamma<1$. In addition, it is expected that $\beta>\gamma$. The equilibrium level of per capita income $\left(y^{*}\right)$ in logs can be expressed as a function of the stock of matched and mismatched workers as follows:

$$
\log y^{*}=\ln A(0)+g t-\frac{\alpha}{1-\alpha} \log (n+g+\delta)+\frac{\alpha}{1-\alpha} \log \left(s_{k}\right)+\frac{\beta}{1-\alpha} \log (h m)+\frac{\gamma}{1-\alpha} \log (h m i s)
$$

Using the restriction on the regression coefficients for $\log (n+g+\delta)$ and $\log \left(s_{k}\right)$, Equation (3) takes the following form:

$$
\log y^{*}=\ln A(0)+g t+\frac{\alpha}{1-\alpha}\left(\log \left(s_{k}\right)-\log (n+g+\delta)\right)+\frac{\beta}{1-\alpha} \log (h m)+\frac{\gamma}{1-\alpha} \log (\text { hmis })
$$

Equation (4) provides the basis for the empirical models being solved here. The study employs the job analysis static approach to measure the extent of (mis)match. Its main advantage is that it is an objective measure of mismatch. In general, this approach is costly and does not fully reflect the occupational changes. A comprehensive comparative analysis of the indicators used to measure overeducation could be found in Capsada-Munsech (2019).

Here, fixed mapping between workers' education according to the ISCED (International Standard Classification of Education) and their occupations under the International Standard Classification of Occupations (ISCO) is assumed. Data with annual frequency supplied by the Labor Force Survey of the European Statistical Office (EUROSTAT) over the period 2000-2019 are used. The survey represents the distribution of the labor force by a range of occupations following ISCO-08. The usage of the same analytical framework for the construction of this indicator makes it appropriate for cross-country comparisons within the EU.

The sample comprises the $27 \mathrm{EU}$ member states including the United Kingdom but excluding Greece. Over the years 2014-2016, Greece records a negative rate of labor force growth and productivity gains. Therefore, the log transformation could not be performed which leads to missing values for some of the variables included in the model. To prevent biases in results, this country was dropped from the sample. Moreover, due to missing 
values or methodological changes, the year 2000 is excluded for Lithuania. The starting year for Croatia is 2002 while for Malta 2004.

Appendix A outlines major tendencies across the EU countries included in the sample regarding the extent of vertical education-job (mis)match. It displays the average values and the cumulative percentage change over the period 2000-2019 for the rate of mismatch, thus outlining the overall trend over the investigated period. The share of overqualified workers with higher education over the examined period was nearly $19 \%$ of the employed with that degree. This number has risen by $45.6 \%$ cumulatively over the last two decades. The countries with the highest levels of mismatch comprise Spain (35.5\%), Cyprus (34.2\%), and Ireland $(29.1 \%)$. The biggest increases have been reported for the economies with relatively lower initial (in the year 2000) rates of mismatch such as Slovakia, Poland, Malta, and the Czech Republic. There exists a strong positive correlation between the extent of overeducation among the most educated workforce in a given country and the percentage of overeducated employees with upper secondary education (0.73). The latter has increased by almost $41 \%$, thus accounting for $8.6 \%$ on average over the last two decades. In most countries, the cumulative change of overeducated individuals having graduated from ISCED (3-4) is positive. More than double increase has been reported for Italy and Ireland. This was reasonably accompanied by a fall of undereducated with upper secondary education. Their share in the workforce is $10.3 \%$. The analysis of vertical qualification mismatch over the last two decades shows that an increasing percentage of the most educated active population has been taking jobs down the occupational ladder.

In the regression models below (see, Table 1), the variable denoted by vmatch_he represents the stock of properly matched with higher education. It comprises individuals having completed at least a bachelor's degree (ISCED 5-8) working as managers, professionals, technicians, or associate professionals expressed as a percentage of the active population. Tertiary education graduates working at any other position are classified as overeducated (over_he). Regarding upper secondary education, three variables have been constructed. The job categories which define the properly matched employees with upper secondary education (vmatch_use) comprise clerical support workers, service and sales workers, skilled agricultural, forestry and fishery workers, craft and related trades workers, plant and machine operators, and assemblers. Respectively, the undereducated (under_use) include individuals with upper secondary education (ISCED 3-4) working as managers, professionals, technicians, and associate professionals. Workers at elementary occupations are considered overeducated (over_use). The overall stock of human capital (hkstock) is calculated as the percentage of the active population (15-74 years of age) having completed at least upper secondary education (ISCED 3-8). The latter solves the problem of potential correlation between the quantity of human capital and the rate of (mis)match for each of the two academic degrees under consideration.

The explanatory variables also include the rate of investments in physical capital $\left(\mathrm{s}_{\mathrm{k}}\right)$ as was explained above. It is approximated by the fixed capital formation in both public and private institutions expressed as a percentage share of GDP. The parameter $n$ equals the percentage change of the active population between 15 and 74 years of age. The wider age interval guarantees that the employees working beyond the retirement age are also included in the sample. In the relevant studies, the rate of capital depreciation $(\delta)$ is usually set at $3 \%$ annually while $g$ is supposed to equal $2 \%$ per year. To obtain estimates as close as possible to the real-life data, here, $\mathrm{g}$ is approximated by the country's rate of annual productivity growth. For the overall sample, its mean value is 1.74 . Specifically, for the old member states, the value is 0.83 while for the new member countries it is 2.75 . 
Table 1. Description of regression variables.

\begin{tabular}{|c|c|c|c|c|}
\hline \multirow{2}{*}{ Name * } & \multirow{2}{*}{ Description } & \multicolumn{3}{|c|}{ Descriptive Statistics } \\
\hline & & Mean & Min/Max & St. Dev. \\
\hline $\begin{array}{c}\log \mathrm{y} \\
\text { Steady-state per capita output }\end{array}$ & $\begin{array}{l}\text { Real gross domestic product (GDP) per labor force } \\
\text { unit }(2010=100)\end{array}$ & 10.69 & $9.23 / 12.16$ & 0.62 \\
\hline $\log s_{k}-\log (n+g+\delta)^{* *}$ & $\begin{array}{l}\text { Rate of physical capital accumulation, rate of labor } \\
\text { force growth, growth of productivity and } \\
\text { depreciation rate }\end{array}$ & 1.49 & $0.80 / 2.27$ & 0.26 \\
\hline $\begin{array}{l}\text { log vmatch_he } \\
\text { Stock of just-educated employees } \\
\text { with higher education }\end{array}$ & $\begin{array}{c}\text { Employees with higher education working in } \\
\text { positions requiring tertiary education such as } \\
\text { managers, professionals, technicians and associate } \\
\text { professionals (\% labor force) }\end{array}$ & 3.02 & $2.21 / 3.65$ & 0.29 \\
\hline $\begin{array}{l}\text { log over_he } \\
\begin{array}{l}\text { Stock of overeducated with higher } \\
\text { education }\end{array}\end{array}$ & $\begin{array}{l}\text { Employees with higher education holding any } \\
\text { other then the abovementioned jobs (\% labor force) }\end{array}$ & 1.47 & $-0.15 / 2.65$ & 0.66 \\
\hline $\begin{array}{l}\text { log vmatch_use } \\
\text { Stock of just-educated with upper } \\
\text { secondary education }\end{array}$ & $\begin{array}{l}\text { Employees with upper secondary education } \\
\text { working in positions requiring at least secondary } \\
\text { education such as clerical support workers, service } \\
\text { and sales workers, skilled agricultural, forestry and } \\
\text { fishery workers, craft and related trades workers, } \\
\text { plant and machine operators and assemblers (\% } \\
\text { labor force) }\end{array}$ & 3.32 & $1.98 / 3.88$ & 0.40 \\
\hline $\begin{array}{l}\text { log under_use } \\
\text { Stock of undereducated with } \\
\text { upper secondary education }\end{array}$ & $\begin{array}{l}\text { Employees with upper secondary education } \\
\text { working as managers, professionals, technicians } \\
\text { and associate professionals (\% labor force) }\end{array}$ & 2.40 & $1.23 / 3.16$ & 0.40 \\
\hline $\begin{array}{l}\text { log over_use } \\
\text { Stock of overeducated with upper } \\
\text { secondary education }\end{array}$ & $\begin{array}{l}\text { Employees with upper secondary education } \\
\text { working in elementary occupations (\% labor force) }\end{array}$ & 1.26 & $-0.37 / 2.12$ & 0.51 \\
\hline $\begin{array}{l}\log \text { hkstock } \\
\text { Quantity of human capital }\end{array}$ & $\begin{array}{l}\text { Active population (15-74 years of age) having } \\
\text { completed at least upper secondary education } \\
\text { (ISCED 3-8) (\% labor force) }\end{array}$ & 4.32 & $3.22 / 4.56$ & 0.24 \\
\hline
\end{tabular}

* All variables except $y$ are introduced as seven-year averages over the examined period 2000-2019. The variable y is real GDP per unit of active population at the end of each seven-year period. ${ }^{* *} \mathrm{~s}_{\mathrm{k}}$ is the rate of physical capital accumulation measured by the gross fixed capital formation-to-gross domestic product ratio. The rate of growth of the labor force $n$ is calculated as percentage change of the active population between 15 and 74 years of age; the percentage change of annual labor productivity is denoted by $g$ while $\delta$ is the depreciation rate.

Equation (4) links the steady-state per capita income $y^{*}$ to the rate of vertical (mis)match. The regression analysis utilizes panel data combining time series with cross-section data. The long-run effect on per capita income has been simulated by using seven-year averages over the examined period for all explanatory variables. This results in 14 moving average time series observations over the subperiods 2000-2006, 2001-2007, 2002-2008, etc., per country. Thus, the models are solved with a balanced data panel containing a total of 378 observations for each variable included. The dependent variable $(y)$ is real GDP per labor force unit at the end of each seven-year subperiod, i.e., 2006, 2007, 2008, etc.

The purpose of this transformation is two-fold. First, it aims at diminishing or even eliminating the fluctuations related to the business cycle which usually lasts for five to eight years on average, thus allowing for the effect of (mis)match on per capita output in a longer run to be estimated. The contribution of this study is that unlike most similar studies which use five-year moving averages (see, e.g., Islam 1995), seven-year moving averages are applied here to better capture the long-run relationships. Second, it solves the problem of endogeneity of the explanatory variables including those measuring the rate of (mis)match. It is expected that mismatch and output are interrelated. Not only (mis)match affects the level of output and its rate of growth but also changes in economic activity determine the extent of (mis)match. In recession times, overeducation rises since educated 
workers are preferred by employers given the limited available jobs. The opposite is true for the expansionary stage, especially near the peak. Moreover, there might exist reverse causality from output to investments (Ericsson and Irandoust 2001), labor productivity, and labor force growth, if the same year values are used. However, in this case, the output at the end of each seven-year period is linked to the mean values of factor variables over that whole period including preceding years. All variables are expressed in logs.

Table 1 reports the descriptive statistics of the variables in the models. It reflects both time and cross-section differences. As it is evident, the variables denoting the extent of mismatch vary in a wide range. The standard deviation is highest (0.66) for log over_he. It takes both negative and positive values-from -0.15 to 2.65 . The same is valid for overeducated employees with upper secondary education, as the standard deviation for log over_use is 0.51 . The mean value of $\log$ output per unit is 10.7 , while the standard deviation is also comparatively high (0.62). The descriptive statistics show that the variables of main interest significantly differ from country to country, which implies that pool estimations would not yield robust outcomes.

Table 2 presents the outcome-test statistics and $p$-value-of the statistical tests which address the major issues related to panel data estimation such as the presence of unobserved effects, fixed vs. random effects, time and individual effects, heteroscedasticity, and serial correlation in the error term. This aims at finding the empirical models and estimation methods that best fit the data. The results in the table refer to the model examining higher education. The same tests have been performed for the model for upper secondary education $^{2}$.

Table 2. Output from statistical tests.

\begin{tabular}{|c|c|c|}
\hline Test & $p$-Value & Outcome \\
\hline Woolridge's test for unobserved effects & 0.0007 & Presence of unobserved effect \\
\hline $\begin{array}{l}\text { Lagrange Multiplier Test-individual } \\
\text { effects for balanced panels }\end{array}$ & $<2.2 \times 10^{-16}$ & Significant individual effects \\
\hline F-test for individual effects & $<2.2 \times 10^{-16}$ & Significant individual effects \\
\hline \multirow[t]{2}{*}{$\begin{array}{l}\text { Lagrange Multiplier Test-time effects for } \\
\text { balanced panels }\end{array}$} & 0.5998 & No presence of time effects \\
\hline & 0.1739 & No presence of time effects \\
\hline $\begin{array}{l}\text { Random vs. fixed effects } \\
\text { (Hausman test) }\end{array}$ & 0.3835 & Random effect estimation \\
\hline $\begin{array}{l}\text { Lagrange Multiplier Test } \\
\text { (Breusch-Pagan) for random effects }\end{array}$ & $<2.2 \times 10^{-16}$ & $\begin{array}{c}\text { Random effect estimation is preferable to } \\
\text { pooling estimation }\end{array}$ \\
\hline $\begin{array}{l}\text { Breusch-Godfrey/Wooldridge test for } \\
\text { serial correlation in panel models }\end{array}$ & $<2.2 \times 10^{-16}$ & Serial correlation in idiosyncratic errors \\
\hline $\begin{array}{l}\text { Studentized Breusch-Pagan test for } \\
\text { heteroscedasticity }\end{array}$ & 0.1172 & No presence of heteroscedasticity \\
\hline
\end{tabular}

Though the Hausman test favors random effects estimation as it is denoted in Table 2, the regression models are evaluated by three methods for comparative purposes. The instrumental variable method with individual fixed effects (IVfe) and instrumental variable method with individual random effects (INre) have been applied. In the first two cases, the instrumental variable method has been used to solve the problem of multicollinearity between vertical match and vertical mismatch among graduates with a given educational degree completed when introduced in one model. In addition, instrumental variable pooled OLS estimation (IVpool) is also presented though it is not expected to provide robust estimates due to heterogeneity between new and old member countries. To address the problem of serial correlation and potential heterogeneity, Newey and West (1987) robust 
standard errors are reported. As a robustness check, the variable coefficient method is also used (see Section 4).

\section{Empirical Results}

The results for higher education are presented in Table 3, whereas Table 4 displays the output for upper secondary education. As it is clearly visible (see Table 3), in all cases, the rate of qualification mismatch among workers with tertiary education is positively related to GDP per capita and statistically significant at the 5\% level. The variable over_he exhibits either a negative or statistically insignificant impact. The slope coefficient is close to zero in the baseline models ( 1 and 2 ), which confirms the hypothesis that the higher extent of vertical mismatch is not beneficial for the long-run aggregate activity. The effect of properly matched human capital is positive and significant in all cases. Since this is a "log-log" relationship, the coefficient shows the percentage change of per capita output in response to a one percent increase in the share of the vertically matched labor force with higher education. For both the fixed effect and random effect estimation, the result is about 0.36 . For the pooled estimation, the elasticity is larger than 1 .

Table 3. Effect of vertical (mis)match of tertiary education graduates on per capita income.

\begin{tabular}{|c|c|c|c|}
\hline \multicolumn{4}{|c|}{ Dependent Variable: Log Real Gross Domestic Product per Unit of Active Population } \\
\hline Method $^{(a)}$ & IVfe & IVre & IVpool $^{(a)}$ \\
\hline & (1) & (2) & (3) \\
\hline $\log \left(s_{k}\right)-\log (n+g+s)$ & $\begin{array}{c}-0.054^{* *} \\
(0.026)\end{array}$ & $\begin{array}{c}-0.055^{* *} \\
(0.021)\end{array}$ & $\begin{array}{l}0.256 \text { * } \\
(0.106)\end{array}$ \\
\hline log (vmatch_he) & $\begin{array}{c}0.360 * * * \\
(0.089)\end{array}$ & $\begin{array}{c}0.374^{* * *} \\
(0.069)\end{array}$ & $\begin{array}{l}1.321^{* * *} \\
(0.138)\end{array}$ \\
\hline log (over_he) & $\begin{array}{c}0.013 \\
(0.039)\end{array}$ & $\begin{array}{c}0.008 \\
(0.031)\end{array}$ & $\begin{array}{c}-0.231^{* * *} \\
(0.062)\end{array}$ \\
\hline $\begin{array}{c}\text { Number of } \\
\text { observations }\end{array}$ & 378 & 378 & 378 \\
\hline adj. Rsqr. & 0.34 & 0.37 & 0.26 \\
\hline
\end{tabular}

***,**, * Significance at $1 \%, 5 \%$, and $10 \%$ level, respectively. ${ }^{(a)}$ Intercept is also included in the model. Newey and West robust standard errors are displayed in the parentheses.

Table 4. Effect of vertical (mis)match of employees with upper secondary education on per capita income.

\begin{tabular}{|c|c|c|c|c|}
\hline \multicolumn{5}{|c|}{ Dependent Variable: Log Real Gross Domestic Product per Unit of Active Population } \\
\hline Method $^{(a)}$ & IVfe & IVre & IVfe & IVre \\
\hline & (1) & (2) & (3) & (4) \\
\hline $\log s_{k}-\log (n+g+s)$ & $\begin{array}{c}-0.039 \\
(0.027)\end{array}$ & $\begin{array}{l}-0.042 \\
(0.029)\end{array}$ & $\begin{array}{c}-0.045 * \\
(0.027)\end{array}$ & $\begin{array}{l}-0.034 \\
(0.021)\end{array}$ \\
\hline log vmatch_use & $\begin{array}{c}0.394^{* * *} \\
(0.105)\end{array}$ & & & $\begin{array}{c}0.360^{* * *} \\
(0.080)\end{array}$ \\
\hline log over_use & $\begin{array}{c}0.009 \\
(0.050)\end{array}$ & $\begin{array}{c}0.043 \\
(0.052)\end{array}$ & $\begin{array}{c}0.047 \\
(0.049)\end{array}$ & $\begin{array}{l}-0.002 \\
(0.034)\end{array}$ \\
\hline log under_use & $\begin{array}{c}-0.543^{* * *} \\
(0.068)\end{array}$ & $\begin{array}{c}-0.413^{* * *} \\
(0.068)\end{array}$ & $\begin{array}{c}-0.428^{* * *} \\
(0.069)\end{array}$ & $\begin{array}{c}-0.513^{* * *} \\
(0.047)\end{array}$ \\
\hline Number of observations & 378 & & 378 & 378 \\
\hline Rsqr. & 0.29 & 0.23 & 0.25 & 0.23 \\
\hline
\end{tabular}

***,**,* Significance at $1 \%, 5 \%$, and $10 \%$ level, respectively. ${ }^{(a)}$ Intercept is included in all models. Newey and West robust standard errors are displayed in the parentheses. 
The coefficient for $\left(\log \left(s_{k}\right)-\log (n+g+s)\right)$ changes its sign. For the pool estimation, it is positive and significant as expected but in the other two cases, it is close to zero. The correlation coefficients between the seven-year moving averages and end-of-period GDP per labor force unit per country are mostly negative, which might explain the result. The correlation is -0.13 for $s_{k}$. It seems that investments in fixed assets have not contributed to the increase in economic activity over the investigated period. Another reason might be the seven-year duration of the sub-periods, which suppresses the impact of investments on growth.

Table 4 shows the results for upper secondary education. Here, the Hausman test favors the introduction of fixed effects, but random effect estimation is also presented for comparative purposes. Moreover, since, in this case, the group of the vertically mismatched comprises the undereducated as well as the overeducated, the models differentiate between their impacts. In all cases, the positive effect of the vertically mismatched on the steady-state level of income has been confirmed. The increase in the share of the undereducated leads to a lower per capita GDP, as the coefficient is statistically significant. These are graduates from secondary schools in occupations such as managers, professionals, technicians, and associate professionals. In the EU, their share among the employees with that educational level is nearly $27 \%$. In 2019 , it was $10 \%$ lower than that in the year 2000 . So, the diminishing percentage of undereducated plays a beneficial impact on the economic activity in the long run. The impact of the overeducated is almost zero, and not significant. In general, the outcome confirms the hypothesis that the increasing rate of vertical qualification mismatch does not contribute positively to the steady-state per capita output.

The relatively low Rsqr. value of the models might reflect the methodology of the study. Similar papers relate log GDP at a given year to five-year averages of the regression variables-human capital proxies, rate of population growth, etc. (e.g., Islam 1995; Kostov and Le Gallo 2018). Here, as was mentioned above, seven-year averages have been used to reduce the effect of business cycle fluctuations on the investigated relations. In this way, the longer-term effect of vertical (mis)match is better examined though at the expense of reduced model's explanatory power.

\section{Robustness of the Regression Output and Discussion}

To test the robustness of regression outcomes for both tertiary and upper secondary education, the models have been re-estimated by changing their structure as well as the method of estimation. First, the overall country's stock of human capital or its interaction with the vertically matched individuals is included as an additional control variable. It is measured by the active population having completed at least upper secondary education, which solves the issue of potential multicollinearity between this new variable and the vertical (mis)match indicators. The models are solved using the same methods as those in the previous section. The results of these robustness checks are given in Table 5. Additionally, the models presented in the previous section have been estimated using the variable coefficient method. The results are summarized in Table 6.

Table 6 summarizes the effect of both educational levels considered. Though the effect of the overall human capital stock (log hkstock) varies across the different estimation methods, the slope of the interaction term between the quantity of human capital and vertically matched individuals with tertiary education (log vmatch_he*hkstock) remains positive and statistically significant at the $5 \%$ level in all cases. This confirms that the higher share of properly matched human capital exhibits a positive impact on the long-run changes in economic activity. Moreover, this is true for both tertiary education graduates (models 2, 3, and 4) and workers with having completed secondary education (models 5 and 6). The impact of "education-job" mismatch at both levels keeps its negative sign. 
Table 5. Robustness checks: introduction of the human capital stock in the models.

\begin{tabular}{|c|c|c|c|c|c|c|}
\hline \multicolumn{7}{|c|}{ Dependent Variable: Log Real Gross Domestic Product per Unit of Active Population } \\
\hline Method & Pooled OLS ${ }^{(a)}$ & IVfe & IVfe & IVre & IVfe & IVre \\
\hline & (1) & (2) & (3) & (4) & (5) & (6) \\
\hline $\log \left(s_{k}\right)-\log (n+g+s)$ & $\begin{array}{l}0.274^{* *} \\
(0.124)\end{array}$ & $\begin{array}{c}-0.118^{* * *} \\
(0.028)\end{array}$ & $\begin{array}{l}-0.090 \\
(0.019)\end{array}$ & $\begin{array}{c}-0.089 * * * \\
(0.030)\end{array}$ & $\begin{array}{c}-0.049 * \\
(0.025)\end{array}$ & $\begin{array}{c}-0.052 * \\
(0.029)\end{array}$ \\
\hline log vmatch_he & $\begin{array}{c}1.373^{* * *} \\
(0.160)\end{array}$ & $\begin{array}{c}0.345^{* * *} \\
(0.10)\end{array}$ & $\begin{array}{c}0.268^{* * *} \\
(0.076)\end{array}$ & $\begin{array}{c}0.288^{* * *} \\
(0.076)\end{array}$ & & \\
\hline log over_he & $\begin{array}{c}-0.133^{* *} \\
(0.066)\end{array}$ & $\begin{array}{c}-1.503^{* * *} \\
(0.353)\end{array}$ & $\begin{array}{c}-0.992 \text { ** } \\
(0.413)\end{array}$ & $\begin{array}{c}-0.096 \text { ** } \\
(0.473)\end{array}$ & & \\
\hline $\log$ hkstock & $\begin{array}{c}-1.010 * * * \\
(0.162)\end{array}$ & $\begin{array}{c}-0.199 * * \\
(0.09)\end{array}$ & & & & $\begin{array}{c}0.382^{* * *} \\
(0.123)\end{array}$ \\
\hline log vmatch_he * hkstock & & $\begin{array}{c}0.350 * * * \\
(0.081)\end{array}$ & $\begin{array}{l}0.237 * * \\
(0.093)\end{array}$ & $\begin{array}{l}0.226^{* *} \\
(0.1070\end{array}$ & & \\
\hline log vmatch_use ${ }^{*}$ hkstock & & & & & $\begin{array}{c}0.076^{* * *} \\
(0.013)\end{array}$ & $\begin{array}{l}0.283^{* *} \\
(0.130)\end{array}$ \\
\hline log over_use & & & & & $\begin{array}{l}-0.002 \\
(0.047)\end{array}$ & $\begin{array}{l}-0.051 \\
(0.061)\end{array}$ \\
\hline log under_use & & & & & $\begin{array}{c}-0.516^{* * *} \\
(0.062)\end{array}$ & $\begin{array}{c}-0.519 * * * \\
(0.066)\end{array}$ \\
\hline Number of observations & 378 & 378 & 378 & 378 & 378 & 378 \\
\hline Adj. Rsqr. & 0.34 & 0.46 & 0.43 & 0.45 & 0.36 & 0.32 \\
\hline
\end{tabular}

$* * *, * *, *$ Significance at $1 \%, 5 \%$, and $10 \%$ level, respectively. ${ }^{(a)}$ Intercept is included in all models. Newey and West robust standard errors are displayed in the parentheses.

Table 6 sheds light on the outcome of the variable coefficient estimation method. It is useful when data do not support the same coefficients over different cross-sections or times. It allows for variations in parameters across cross-sectional units as an instrument to take account of the heterogeneity (Hsiao 2003). The output supports the results in the previous section regarding tertiary education. The extent of the vertical match is positively correlated with GDP per capita changes, while overeducation is not statistically significant. In the latter case, there are significant differences across the countries in the sample. In the case of secondary education, the regression coefficients for properly matched and undereducated keep their sings-positive for the former and negative for the latter.

Overall, this section proves the robustness of the baseline models and estimation. It confirms that the higher extent of vertical qualification match among tertiary education, as well as secondary education graduates, is expected to lead to a higher steady-state per capita output level. Yet, the effect of mismatch is either negative or close to zero and statistically insignificant. The negative impact of overeducation is more strongly expressed for higher education than for secondary education. This might be because the latter includes workers performing elementary occupations accounting for a small share in the national labor market. The impact of undereducated with secondary education is also negative. 
Table 6. Robustness checks: variable coefficients estimation.

\begin{tabular}{|c|c|c|c|c|}
\hline \multicolumn{5}{|c|}{ Tertiary Education } \\
\hline & \multicolumn{2}{|c|}{$\log \left(s_{k}\right)-\log (n+g+s)$} & log vmatch_he & log over_he \\
\hline Random effects & \multirow{2}{*}{\multicolumn{2}{|c|}{$\begin{array}{c}-0.123^{* * *} \\
(0.041)\end{array}$}} & $0.430 * * *$ & -0.036 \\
\hline Estimated mean of the coefficients & & & $(0.092)$ & $(0.113)$ \\
\hline \multicolumn{5}{|c|}{ Fixed effects } \\
\hline Minimum & \multicolumn{2}{|c|}{-0.540} & -0.627 & -1.621 \\
\hline Median & \multicolumn{2}{|c|}{-0.116} & 0.282 & 0.116 \\
\hline Mean & \multicolumn{2}{|c|}{-0.123} & 0.440 & -0.010 \\
\hline Max & \multicolumn{2}{|l|}{0.619} & 1.991 & 1.916 \\
\hline \multirow[t]{3}{*}{$\begin{array}{c}\text { Chi sqr } \\
\text { ( } p \text {-value) }\end{array}$} & \multicolumn{4}{|c|}{$\begin{array}{l}29.523 \\
(0.000)\end{array}$} \\
\hline & \multicolumn{2}{|c|}{ Upper Secondary Education } & & \\
\hline & $\log \left(s_{k}\right)-\log (n+g+s)$ & log vmatch_use & log under_use & log over_use \\
\hline Random effects & $-0.094^{* * *}$ & 0.691 & -0.232 & -0.075 \\
\hline Estimated mean of the coefficients & $(0.027)$ & $(0.523)$ & $(0.165)$ & $(0.148)$ \\
\hline \multicolumn{5}{|c|}{ Fixed effects } \\
\hline Minimum & -0.270 & -1.728 & -1.985 & -2.023 \\
\hline Median & -0.106 & 0.349 & -0.415 & 0.054 \\
\hline Mean & -0.550 & 0.267 & -0.376 & 0.036 \\
\hline Max & 0.805 & 3.123 & 1.370 & 1.463 \\
\hline $\begin{array}{l}\text { Chi sqr } \\
\text { (p-value) }\end{array}$ & & $\begin{array}{l}18.111 \\
(0.001)\end{array}$ & & \\
\hline
\end{tabular}

$* * *, * *,{ }^{*}$ Significance at $1 \%, 5 \%$, and $10 \%$ level, respectively.

The results are in compliance with the abovementioned papers in the field of organizational behavior, mainly recognizing the likelihood of a negative effect of overeducation on productivity (see, e.g., Rumberger 1987; Tsang et al. 1991; Verhaest and Omey 2009). Moreover, it supports the view of McGowan and Andrews (2015) who attribute the negative impact of the overeducated on the overall activity to misallocation of resources.

Two cases might be differentiated for overeducated. The individuals who work at occupations down the ladder but possess higher than required educational degrees could not fully utilize the acquired skills and knowledge, thus adding lower than the expected value. Those might be well-educated individuals with academically oriented degrees but lacking practically oriented skills or just the right skills and competencies necessary for the job they perform. Examples might be given with employees with higher education working as sales representatives, administrative support specialists, etc. In addition to vertical mismatch, they might experience horizontal mismatch as well.

This could be denoted as an "overeducation-overskilling" case. It might arise since the likelihood of finding a job corresponding to one's completed educational degree depends not only on his or her skills, competencies, and capabilities but also on the economy's structure. Therefore, such a mismatch is expected when the economic structure of a given country does not correspond to the graduates' profile, thus leading to an oversupply of education. Though well-educated, workers move down the occupational ladder because the labor market does not provide enough jobs to meet the supply of graduates qualified for these jobs. Employers might hire such a workforce taking their higher than needed education as a signal for a good background and personal qualities. This type of mismatch cannot persist. The equilibrium between the quantity demanded and the quantity supplied of a certain educational level would be achieved in the future mainly because people are expected to adapt their qualifications to the labor market needs. However, in the case of 
government-financed education, the path toward equilibrium might take longer than in the case of privately funded education, thus adversely affecting potential output.

A second case assumes an imperfect match between one's education and skilling. It would be characterized as an "overeducation-underskilling" case. It might result from a mismatch between skills expected and hence demanded by the employers for a specific educational level and skills achieved and respectively supplied by individuals having attained that educational level. If employers hire workers not according to the formal educational requirements for a specific job but according to one's actual qualification and personal qualities, it is likely that people who have not acquired the presumed knowledge, skills, and competencies corresponding to their education would be employed at positions down the occupational ladder regardless of the educational degree completed. The higher the share of these workers, the higher the likelihood for a negative impact of education on productivity and output since they add lower than expected value, and education spending has not been efficiently allocated as well. This situation might be resolved by improved education quality and imposition of educational standards, assuring compliance between expected and acquired qualifications of the graduates. The negative effect of undereducation on output might be explained by the lower productivity of workers with lower than required education in comparison with their just-educated peers due to inadequate skills and knowledge especially in times of technological changes.

\section{Conclusions}

This paper aims at bringing new evidence on the long-run effect of "education-job" mismatch among the most educated workforce on per capita gross domestic product. It was motivated by the growing share of employees who work below their qualifications (Mavromaras et al. 2013). One of its contributions is that it differentiates between the macroeconomic impact of qualification mismatch across different educational degrees, specifically tertiary and upper secondary education. The results cannot find evidence that overeducation is positively related to output per capita level in the long run. Moreover, there is some evidence that overeducation among tertiary education graduates (ISCED 5-8) exhibits a stronger negative impact in comparison with overeducation among workers having completed upper secondary education (ISCED 3-4). The increasing percentage of the properly matched individuals across both educational degrees being examined is always positively correlated with output per capita. In general, the study implies that the effect of education on growth is conditional upon the labor market outcome for the graduates. This result calls for more attention to government policies in the field of education, especially its compliance with the labor market demand and requirements. It seems that the automatic imposition of targets for the quantity of human capital at a national level could cause an oversupply of the educated labor force, a rise of mismatch, an inefficient allocation of public as well as private resources, and consequently an adverse effect on economic activity in a longer run.

Funding: This research received no external funding.

Data Availability Statement: This study uses data openly available at: https://ec.europa.eu/ eurostat, accessed on 30 October 2020.

Acknowledgments: I would like to thank to the Editor and two anonymous reviewers for their helpful comments and suggestions. The study was supported by the project IRISI under a contract № KP/06/OPR 01/4/21.12.2018 with Bulgarian Scientific Fund.

Conflicts of Interest: The author declares no conflict of interest. 
Appendix A. Extent of Qualification Mismatch across the EU Countries (2000-2019)

\begin{tabular}{|c|c|c|c|c|c|c|}
\hline \multirow{3}{*}{ Country } & \multirow{2}{*}{\multicolumn{2}{|c|}{$\begin{array}{c}\text { Tertiary Education } \\
\text { (ISCED 5-8) } \\
\text { Overeducated } \\
\text { (\% Employed with Higher } \\
\text { Education) }\end{array}$}} & \multicolumn{4}{|c|}{$\begin{array}{l}\text { Upper Secondary Education } \\
\text { (ISCED 3-4) }\end{array}$} \\
\hline & & & \multicolumn{2}{|c|}{$\begin{array}{c}\text { Overeducated } \\
\text { (\% Employed with Upper } \\
\text { Secondary Education) }\end{array}$} & \multicolumn{2}{|c|}{$\begin{array}{c}\text { Undereducated } \\
\text { (\% Employed with Upper } \\
\text { Secondary Education) }\end{array}$} \\
\hline & Average Value & $\begin{array}{c}\text { Cumulative } \\
\text { Percentage } \\
\text { Change }\end{array}$ & Average Value & $\begin{array}{c}\text { Cumulative } \\
\text { Percentage } \\
\text { Change }\end{array}$ & Average Value & $\begin{array}{c}\text { Cumulative } \\
\text { Percentage } \\
\text { Change }\end{array}$ \\
\hline Austria & 24.4 & 34.9 & 7.7 & 21.2 & 31.2 & 2.6 \\
\hline Belgium & 21.7 & -8.9 & 10.6 & 26.4 & 26.3 & -15.4 \\
\hline Bulgaria & 22.1 & 32.2 & 10.6 & 6.7 & 15.1 & -37.5 \\
\hline Croatia & 13.6 & 15.1 & 6.2 & 80.8 & 19.7 & -6.1 \\
\hline Cyprus & 34.2 & 7.9 & 16.0 & 95.9 & 15.6 & -21.4 \\
\hline Czech Republic & 10.5 & 112.4 & 5.4 & -4.7 & 28.1 & -21.2 \\
\hline Denmark & 14.1 & 24.4 & 8.7 & 8.7 & 30.7 & 2.7 \\
\hline Estonia & 26.1 & 3.3 & 11.1 & -6.2 & 25.6 & 19.2 \\
\hline Finland & 19.3 & -7.7 & 9.2 & 4.3 & 23.8 & -21.6 \\
\hline France & 21.2 & 19.8 & 9.3 & 83.2 & 27.1 & 6.2 \\
\hline Germany & 21.1 & -22.9 & 7.3 & 0.88 & 32.1 & 15.4 \\
\hline Greece & 25.5 & 55.1 & 5.9 & 45.3 & 19.8 & -45.6 \\
\hline Hungary & 13.3 & 42.6 & 6.6 & 85.1 & 21.2 & -21.1 \\
\hline Ireland & 29.1 & 22.5 & 9.0 & 101.3 & 23.7 & -21.4 \\
\hline Italy & 17.1 & 47.5 & 6.4 & 108.4 & 38.7 & -19.3 \\
\hline Latvia & 19.6 & 41.2 & 15.1 & 22.4 & 23.5 & -13.6 \\
\hline Lithuania & 21.5 & 11.4 & 12.5 & 41.2 & 16.6 & -13.7 \\
\hline Luxemburg & 5.0 & 77.7 & 5.2 & 114.0 & 39.6 & -3.1 \\
\hline Malta & 11.9 & 154 & 3.2 & 9.2 & 39.7 & 9.2 \\
\hline Netherlands & 16.5 & 18.3 & 6.4 & 35.9 & 39.2 & -21.2 \\
\hline Poland & 16.7 & 180.0 & 8.1 & 1.6 & 19.6 & -19.6 \\
\hline Portugal & 13.0 & 44.1 & 7.1 & 32.0 & 33.1 & -19.1 \\
\hline Romania & 14.8 & 58.6 & 8.5 & 22.1 & 13.5 & -29.8 \\
\hline Slovakia & 14.9 & 185.0 & 8.5 & -18.5 & 23.1 & -32.4 \\
\hline Slovenia & 11.8 & 97.1 & 5.5 & 94.7 & 25.7 & -7.5 \\
\hline Spain & 35.5 & 4.0 & 12.1 & 52.3 & 21.9 & -37.3 \\
\hline Sweden & 15.5 & 5.5 & 5.2 & -7.0 & 31.8 & 38.2 \\
\hline UK & 23.9 & 31.6 & 10.3 & 88.8 & 30.3 & 10.2 \\
\hline EU-28 & 19.1 & 45.6 & 8.5 & 40.9 & 26.3 & -11.6 \\
\hline
\end{tabular}

\section{Notes}

Greece is excluded from the sample due to missing values for some of the variables used in the models.

The results are available upon request. 


\section{References}

Barrick, Murray, and Michael Mount. 1991. The five big personality dimensions and job performance: A meta-analysis. Personnel Psychology 44: 1-26. [CrossRef]

Bauer, Thomas. 2002. Educational Mismatch and Wages: A Panel Analysis. Economics of Education Review 21: 221-29. [CrossRef]

Birk, Angela. 2001. Qualification-Mismatch and Long-Term Unemployment in a Growth-Matching Model (No. 128). HWWA Discussion Paper. Hamburg: HWWA.

Capsada-Munsech, Queralt. 2019. Measuring overeducation: Incidence, correlation and overlaps across indicators and countries. Social Indicators Research 145: 279-301. [CrossRef]

Dorn, David, and Alfonso Sousa-Poza. 2005. Overqualification: Permanent or transitory? Mimeo: University of St. Gallen.

Ericsson, Johan, and Manuchehr Irandoust. 2001. On the causality between foreign direct investments and output: A comparative study. The International Trade Journal 15: 1-26. [CrossRef]

Eurostat. 2009. The Bologna Process in Higher Education in Europe. Key Indicators on the Social Dimension and Mobility. Luxembourg: Office for Official Publications of the European Communities.

Forth, John, and Geoff Mason. 2006. Do ICT Skill Shortages Hamper Firms' Performance? Evidence from UK Benchmarking Surveys (No. 281). National Institute of Economic and Social Research Discussion Papers. London: National Institute of Economic and Social Research.

Garcia-Mainar, Inmaculada, and Victor Montuenga. 2019. The signaling role of over-education and qualification mismatch. Journal of Policy Modelling 41: 99-119. [CrossRef]

Hartog, Joop. 2000. Over-education and earnings: Where we are, where should we go? Economics of Education Review 19: 131-47. [CrossRef]

Hsiao, Cheng. 2003. Variable-Coefficient Models. In Analysis of Panel Data (Econometric Society Monographs). Cambridge: Cambridge University Press, pp. 141-87. [CrossRef]

Islam, Nazrul. 1995. Growth empirics: A panel data approach. Quarterly Journal of Economics 110: 1127-70. [CrossRef]

Jaoul-Grammare, Magali, and Jean-Pascal Guironnet. 2009. Does Over-education Influence French Economic Growth? Economics Bulletin 29: 1190-200.

Kostov, Philip, and Julie Le Gallo. 2018. What role for human capital in the growth process: New evidence from endogenous latent factor panel quantile regression. Scottish Journal of Political Economy 65: 501-27. [CrossRef]

Lucas, Robert. 1988. On the mechanism of economic development. Journal of Monetary Economics 22: 3-42. [CrossRef]

Lucifora, Claudio, and Federica Origo. 2002. The Economic Costs of the Skills Gap in the EU. Milan: Istituto per la Ricerca Sociale.

Mahy, Benoit, Francois Rycx, and Guillaume Vermeylen. 2015. Educational Mismatch and Firm Productivity: Do Skills, Technology and Uncertainty Matter? IZA Discussion Paper No. 8885. Bonn: Institute for the Study of Labor.

Mankiw, Gregory, David Romer, and David Weil. 1992. A contribution to the empirics of economic growth. Quarterly Journal of Economics 107: 407-37. [CrossRef]

Mavromaras, Kostas, Stephane Mahuteau, Peter Sloane, and Zhang Wei. 2013. The effect of overskilling dynamics on wages. Education Economics 21: 281-303. [CrossRef]

McGowan, Adalet, and Dan Andrews. 2015. Labor Market Mismatch and Labor Productivity: Evidence from PIAAC Data. OECD Economics Department Working Papers, N1209. Paris: OECD Publishing.

McGuinness, Seamus, and Peter Sloane. 2011. Labour market mismatch among UK graduates: An analysis using REFLEX data. Economics of Education Review 30: 130-45. [CrossRef]

Newey, Whitney, and Kenneth West. 1987. A Simple, Positive Semi-definite, Heteroskedasticity and Autocorrelation Consistent Covariance Matrix. Econometrica 55: 703-8. [CrossRef]

Nonneman, Walter, and Patrick Vanhoudt. 1996. A further augmentation of the Solow model and the empirics of economic growth for OECD countries. Quarterly Journal of Economics 111: 943-53. [CrossRef]

Quintini, Glenda. 2011. Over-Qualified or Under-Skilled: A Review of Existing Literature. OECD Social, Employment and Migration Working Papers, No. 121. Paris: OECD Publishing.

Ramos, Raul, Jordi Suriñach, and Manuel Artis. 2009. Regional Economic Growth and Human Capital: The Role of Overeducation. WP 2009/04. Barcelona: University of Barcelona, Research Institute of Applied Economics.

Romer, Paul. 1986. Increasing returns and long-run growth. Journal of Political Economy 94: 1002-37. [CrossRef]

Rumberger, Russell. 1987. The impact of surplus schooling on productivity and earnings. Journal of Human Resources 22: 24-50. [CrossRef]

Sloane, Peter, Harminder Battu, and Paul Seaman. 1999. Overeducation, undereducation and the British labour market. Applied Economics 31: 1437-53. [CrossRef]

Spence, Michael. 1973. Job Market Signalling. Quarterly Journal of Economics 87: 355-74. [CrossRef]

Tsang, Mun, Russell Rumberger, and Henry Levin. 1991. The impact of surplus schooling on worker productivity. Industrial Relations 30: 209-28. [CrossRef]

Van der Meer, Peter. 2006. The validity of two education requirement measures. Economics of Education Review 25: 211-19. [CrossRef]

Verdugo, Richard, and Naomi Verdugo. 1989. The impact of surplus schooling on earnings. Journal of Human Resources 24: 629-43. [CrossRef] 
Verhaest, Dieter, and Eddy Omey. 2009. Objective over-education and worker well-being: A shadow price approach. Journal of Economic Psychology 30: 469-81. [CrossRef]

Weiss, A. 1995. Human capital vs. signaling explanation of wages. Journal of Economic Perspectives 9: 133-54. [CrossRef] 